\title{
MENYUSUI DARI PERSPEKTIF SOSIAL BUDAYA
}

NURUL AZIZAH HAMID

70200120049

Univesitas Islam Negeri Alauddin Makassar

Email : iccaicca1717@gmail.com

\section{PENDAHULUAN}

ASI merupakan makanan utama dan paling sempurna bagi bayi. Dimana ASI mengandung hampir semua zat gizi dengan komposisi sesuai dengan kebutuhan bayi untuk tumbuh dan berkembang secara optimal.

Organisasi Kesehatan Dunia (WHO) merekomendasikan ASI eksklusif sebagai strategi penting untuk mengurangi kematian anak, khususnya di negara berkembang. ASI eksklusif didefinisikan sebagai pemberian ASI kepada bayi tanpa disertai apapun bahan selain ASI untuk enam bulan pertama (tidak ada makanan atau cairan termasuk air)

ASI adalah makanan alami dan optimal untuk bayi di pertama 6 bulan hidup, karena menyediakan semua nutrisi yang diperlukan untuk mereka pertumbuhan dan pengembangan. Selain itu pemberian ASI, dikaitkan dengan penurunan resiko infeksi dan penyakit selama masa kanak-kanak (asma, dermatitis, obesitas dan dengan IQ lebih tinggi dan pada ibu akan menurunkan resiko kanker payudara, diabetes dan kanker ovarium.

Al-Quran sebagai pedoman hidup telah menjelaskan peran orang tua dalam mengasuh/mendidik anak. Berbagai dalil dalam Al-Quran dan Hadis dipaparkan pada 
pembahasan islmic parenting menerangkan tentang pengasuhan anak yang dijadikan sebagai landasan merawat anak sehingga tumbuh kembang anak optimal pada setiap fase pertumbuhan dan perkembangannya. Penting bagi orang tua senantiasa memberikan perhatian serius dan menerapkan pola asah, asih dan asuh pada usia pertumbuhan dan perkembangan anak terutama pada usia emas "golden age" di awal kehidupannya yaitu usia nol sampai lima tahun (0-60 bulan). Usia balita adalah masa kritis tumbuh kembang anak, pola pengasuhan pada usia tersebut menjadi pondasi dasar dari berbagai aspek pertumbuhan dan perkembangan anak sehingga terbentuk generasi yang sehat dan religius

\section{PENTINGNYA PEMBERIAN ASI}

Salah satu penelitian yang telah dilakukan di Kelurahan Dannuang Kecamatan Ujung Loe Kabupaten Bulukumba Tahun 2016 memperlihatkan pentingnya asi ekslusif bagi bayi, karena asi juga menjadi indicator penting kesehatan bayi.

Dampak dari tidak memberikan asi pada bayi melainkan memberikan susu formula, salah satu dampaknya membuat tingkat diare pada balita tinggi. Menurut hasil Riskesdas tahun 2013, insiden penyakit diare pada balita adalah 17,0\%, CFR Kejadian Luar Biasa (KLB) diare di Indonesia pada tahun 2011 adalah 0,29\% meningkat menjadi 2,06\% di tahun 2012 lalu mengalami penurunan di tahun 2013 menjadi $1,08 \%$. Sedangkan pada tahun 2013 sulawesi selatan ada pada perinkat ketiga setelah Papua dan NTT yaitu 10,2\% balita yang penderita diare.

Pada Puskesmas Ujung Loe di laporkan bahwa jumlah Penyakit Diare pada tahun 2013 sebanyak 1051 kasus, pada tahun 2014 sebanyak 1056 kasus, dan pada tahun 2015 sebanyak 1059 kasus. Pada Bulan januari sampai agustus 2016 sebanyak 
487. Dimana desa Dannuang tercatat sebagai desa yang tertinggi terkena penyakit diare pada bayi balita sebanyak 83 kasus dibandinkan desa lainnya hanya 67 kasus di Desa Garanta, di Desa Salemba sebanyak 63 kasus. Lonrong 51 Kasus, Manjalling 50 kasus, Seppang 41 Kasus, Padang Loang 24 Kasus dan di Desa Bijawang 8 Kasus Diare.

Dari hasil penelitian tersebut dipaparkan bahwa

(1) Dari hasil penelitian yang dilakukan Di Kelurahan Dannuang Kec. Ujung Loe Kab. Bulukumba Tahun 2016, tidak ada hubungan antara kebiasaan mencuci tangan sebelum mengencerkan susu formula dengan kejadian diare pada bayi 0-6 Bulan dimana nilai $\mathrm{p}=.0 .228$ Ini berarti lebih Besar dari nilai $\alpha=0.05$ yang berarti kebiasaan mencuci tangan sebelum mengencerkan susu dalam penelitian ini tdk mempengaruhi terjadinya penyakit diare pda bayi.

(2) Dari hasil penelitian yang dilakukan Di Kelurahan Dannuang Kec. Ujung Loe Kab. Bulukumba Tahun 2016, Ada hubungan antara membersihkan botol susu formula dengan kejadian diare pada bayi 0-6 Bulan dimana nilai $\mathrm{p}=.0 .002$ Ini berarti lebih Kecil dari nilai $\alpha=0.05$ yang berarti bahwa membersihkan botol susu sebelum menggunakan kepada bayi sangat mempengaruhi dikarenakan kebersihan sangat mempengaruhi berkembang biaknya bakteri atau kuman yang bisa menimbulkan penyakit diare.

(3) Dari hasil penelitian yang dilakukan Di Kelurahan Dannuang Kec. Ujung Loe Kab. Bulukumba Tahun 2016, Ada hubungan antara Penyimpanan botol susu formula dengan kejadian diare pada bayi 0-6 Bulan diperoleh nilai $\mathrm{p}=.0 .000$ Ini berarti lebih Kecil dari nilai $\alpha=0.05$. yang berarti bahwa penyimpanan botol yang baik akan mengurangi terjadinya penyakit diare pada bayi. 
(4) Dari hasil penelitian yang dilakukan Di Kelurahan Dannuang Kec. Ujung Loe Kab. Bulukumba Tahun 2016, Ada hubungan antara cara mengencerkan susu formula dengan kejadian diare pada bayi 0-6 Bulan diperoleh nilai $\mathrm{p}=.0 .000$ Ini berarti lebih Kecil dari nilai $\alpha=0.05$. yang berarti cara mengencerkan susu formula sangat mempengaruhi terjadinya diare dikarenakan frekuensi yang dibutuhkan untuk mengencerkan susu mempunyai atauran yang ada pada setiap susu formula.

\section{TINGKAT PEMBERIAN ASI}

Berdasarkan hasil penelitian yang telah dilakukan di Palembang oleh mahasiswa universitas sriwijaya menunjukka bahwa hanya $70 \%$ dari responden yang memberikan ASI eksklusif pada bayinya. Hal ini menunjukkan bahwa praktek pemberian ASI eksklusif di kota Palembang masih belum mencapai target yang menjadi indikator Indonesiasehattahun 2015 dengan target yaitu $80 \%$. Penelitian ini sejalan dengan data Dinas Kesehatan kota palembang (2014) bahwa cakupan pemberian ASI eksklusif pada bayi 0-6 bulan belum mencapai target Nasional (74,18\%). Rekomendasi pemberian ASI eksklusif sampai usia 6 bulan tampaknya masih terlalu sulit untuk dilaksanakan. Sasaran program perbaikan gizi masyarakat untuk meningkatkan ASI eksklusif hingga $80 \%$ tampak terlalu tinggi. Padahal, pemberian asi eksklusif pada bayi akan memberikan dampak yang luas terhadap status gizi bayi dan ibu dikemudian hari.

Pemberian ASI eksklusif oleh responden yang memiliki jumlah anak $\mathcal{S}$ orang berhubungan secara signifikan terhadap pemberian ASI eksklusif pada bayi. ibu yang memberikan ASI eksklusif rata-rata memiliki paritas yang lebih tinggi tinggi (3 anak) dari pada ibu yang tidak memberikan asi eksklusif (2 anak). Hal ini 
disebabkan jumlah anak akan berpengaruh terhadap pengalaman ibu mengenai menyusui.

Faktor tingkat pemberian asi juga yaitu, dukungan suami. Berdasarkan hasil analisis bivariat terdapat hubungan yang signifikan antara dukungan suami saat melahirkan dengan pemberian ASI eksklusif pada bayi. Hal ini sejalan dengan apa yang dikemukakan dengan paramita bahwa seorang suami yang mampu memperlihatkan rasa sayang dan perhatian kepada ibu bisa mengakibatkan seorang ibu

merasa lebih nyaman dan menghasilkan ASI yang berlimpah, serta akan meningkatkan rasa percaya diri ibu.

Dukungan suami berupa kehadiran saat melahirkan dapat memberikan keuntungan emosional atau berpengaruh pada tingkah laku ibu yaitu pemberian ASI eksklusif. Supporting father atau dukungan suami akan memberikan dukungan kepada ibu saat melahirkan dan membangun kepercayaan diri ibu agar mau dan mampu menyusui.

Dukungan ibu/ibu mertua juga memberikan hubungan yang signifikan terhadap pemberian ASI eksklusif pada bayi. Ibu yang dipengaruhi oleh ibu/ibu mertua yang tidak mendukung pemberian ASI eksklusif akan lebih mudah berisiko untuk tidak memberikan ASI eksklusif pada bayinya. Hal ini karena adanya peran orang tua/mertua lebih besar dari peran suami. Secara umum ibu/ibu mertua tidak mengetahui perkembangan pemberian ASI eksklusif pada bayi yang sebaiknya diberikan hingga bayi mencapai usia 6 bulan. 
Teknik menyusui merupakan salah satu faktor yang mempengaruhi produksi ASI dimana bila teknik menyusui tidak benar dapat menyebabkan puting lecet dan menjadikan ibu enggan menyusui dan bayi jarang menyusu karena bayi enggan manyusu akan berakibat kuarang baik, karena isapan bayi sangat berpengaruh pada rangsangan produksi ASI selanjutnya, bahwa perilaku yang didasari pengetahuan akan lebih langsung dari pada perilaku yang tidak disadari oleh pengetahuan

Terdapatnya hubungan antara pengetahuan ibu dengan tehnik menyusui yang benar menegaskan bahwa pengetahuan teknik menyusui yang benar harus diketahui oleh ibu karena dengan keberhasilan menyusui dengan tehnik yang benar maka bayi akan mendapatkan nutrisi yang cukup yang terkandung dalam ASI. Selain itu terdapat juga kebanggaan dalam diri si ibu bahwa dia juga mampu memberikan ASI pada bayinya secara lancar, selain itu dampak lain seperti dampak ekonomi dimana ibu tidak harus mengeluarkan uang untuk membeli susu.

\section{BUDAYA}

Di Indonesia, budaya dan ideologi patriarki masih sangat kental mewarnai berbagai aspek kehidupan dan struktur sosial masyarakat dan memengaruhi aspek masyarakat dalam berinteraksi. Patriarki adalah sistem pengelompokan masyarakat sosial yang mementingkan garis keturunan bapak/laki-laki. Patrilineal adalah hubungan keturunan melalui garis keturunan kerabat pria atau bapak.

Patriarki juga dapat dijelaskan dimana keadaan masyarakat yang menempatkan kedudukan dan posisi laki-laki lebih tinggi dari pada perempuan dalam segala aspek kehidupan sosial, budaya dan ekonomi 
Budaya patriarki dapat dikaitkan dengan peran yang dominan dari seorang suami selaku ayah dalam rumah tangga. Dominansi ayah dalam memberikan input positif berupa dorongan bagi anggota keluarganya dapat dilihat dalam praktik pemberian ASI ekslusif. Melalui dukungan dan

penguatan dalam memengaruhi aksi ibu dalam pemberian ASI, yang didasari ikatan-ikatan patrilinealistik.

Seorang ayah dapat memberikan dukungan yang positif untuk meningkatkan praktik pemberian ASI, dan mempertahanankan dukungan penuh kepada istri dalam memberikan ASI sampai bayi berusia 6 bulan untuk mencapai ASI ekslusif. Misalnya suami bisa membantu istri menyelesaikan pekerjaan rumah ketika istri sedang menyusui, suami dapat ikut menyendawakan bayi setelah selesai menyusui, membantu ibu menyusui saat ditempat umum dengan mengeluarkan kain menyusui, suami dapat menemani istri datang ke kelas-kelas laktasi, memberikan asupan gizi yang cukup kepada ibu untuk memperlancar ASI, mengingatkan istri untuk selalu memberikan ASI saja sampai usia bayi 6 bulan.

Dukungan suami membuat ibu berpeluang 5,1 kali lebih besar dalam kesuksesan pemberian ASI eksklusif daripada yang tidak didukung oleh suami. Lima peran utama untuk dukungan suami adalah pengetahuan, sikap positif, keterlibatan dalam pengambilan keputusan, praktis dukungan, dan dukungan emosional untuk menyusui.

Mengambil peran positif dalam budaya apatriarki, memberikan kesempatan bagi seorang suami selaku ayah bagi untuk bertanggung jawab dalam memberikan dukungan dan motivasi kepada ibu bayi agar sukses mencapai ASI ekslusif. Ketidak seimbangan gender dalam konsep patriarki membuat ayah 
menjadi dominan dalam memberikan dukungan emosional kepada ibu bayi. Sehingga meskipun ibu bayi kurang termotivasi dengan ASI ekslusif, tetapi dengan seorang suami yang mempunyai pandangan positif tentang hal tersebut dapat merubah aksi dari seorang ibu. 


\section{DAFTAR PUSTAKA}

1. Alam $S$, Syahrir S. Hubungan personal hygiene pemberian susu formula dengan kejadian diare pada bayi di kelurahan Dannuang kecamatan ujung Loe kabupaten bulukumba tahun 2006. Hygiene. 3(2)

2. Alam S, Syahrir S .Faktor-faktor yang berhubungan dengan teknik menyusui pada ibu di puskesmas patallassang kabupaten takalar. Al-Sihah : public health Science Journal. 2016; 8(2)

3. Fajar NA, Purnama DH, @all. Hubungan pemberian asi eksklusif dalam prespektif sosial Budaya Di kota Palembang. Jurnal ilmu kesehatan masyarakat. 2018; 9(3)

4. Prasetya F, Sari AY, @all. Budaya Patriarki Dalam Praktik Pemberian ASI Eksklusif . Jurnal Keperawatan. 2019;3(1)

5. Alam, Syamsul and Karini, Tri Addya (2020) Islamic Parenting "Pola Asuh Anak: Tinjauan Perspektif Gizi Masyarakat". Alauddin University Press, Makassar. ISBN 978-602-328-329-3 